\title{
Dinamika Komunikasi Pendidikan pada Era Disrupsi
}

\author{
Rahmad \\ IAIN Palangkaraya \\ rahmad@iain-palangkaraya.ac.id
}

\begin{abstract}
The progress of the times or also known as the era of disruption is mostly human in nature, one of which is education. This change certainly has an impact on humans because it is increasingly individualistic and increasingly busy keeping up with the times. Education is one of the things that has also changed with the implementation of offline learning patterns into learning patterns that must also include online learning. This article uses a type of library research conducted through collecting related data. The great change of time known as disruption is divided into two parts. The first part is a fundamental change related to innovation and the second part starts from the bottom layer. For this reason, communication plays an important role in this era with its dynamics. Educators must be able and accustomed to using multi-directional or multi-directional communication. This communication certainly does not only involve interactions between educators and students and students with other students. This communication can also be between the principal and educators, educators and the principal's education staff with students and other communication links. Education activists and practitioners as well as teachers must certainly respond to this wisely. The use of technology is inevitable. The use of online media for students certainly has an impact on the activities or academic achievement of students at educational institutions. Educators must of course be aware of this wisely. But the presence of educators certainly cannot be replaced by any sophisticated tools, because the emotional connection between students and teachers can never be replaced by any tools.
\end{abstract}

KEYWORDS : Communication, Education, Disruption Era

\section{ABSTRAK}

Kemajuan zaman atau dikenal pula sebagai era disrupsi akan mengakibatkan perubahan yang terjadi. Perubahan tersebut dapat mengakibatkan semakin individualistisnya manusia serta semakin bersemangat mengikuti perkembangan zaman tersebut. Pendidikan juga kerap mengalami perubahan, salah satunya adalah perubahan pola pembelajaran dari pembelajaran offline menjadi pembelajaran online. Artikel ini menggunakan metode penelitian kajian pustaka yang dilakukan melalui pengumpulan data terkait. Perubahan dalam kehidupan manusia terbagi menjadi dua bagian. Bagian pertama adalah perubahan terkait inovasi dan bagian kedua adalah perubahan yang sifatnya mendasar. Dinamika perubahan yang terjadi tentu tidak terlepas dari peran penting komunikasi pada era saat ini. Peran penting tersebut membuat para pendidik harus terbiasa serta mampu menggunakan kondisi satu arah atau banyak arah. Komunikasi ini tentu bukan hanya interaksi antara pendidik dengan siswa atau siswa dengan siswa lainnya. Tetapi komunikasi ini juga terjadi antara kepala sekolah dengan tenaga pendidik, tenaga pendidik dengan tenaga kependidikan, atau antara kepala sekolah dengan siswa serta hubungan komunikasi lainnya. Hal ini tentu harus disikapi dengan bijak. Terkait dinamika tersebut, penggunaan teknologi tentu tidak bisa dihindari. Salah satunya adalah penggunaan media online bagi siswa tentu berdampak pada aktivitas atau prestasi akademik siswa di lembaga pendidikan. Tetapi yang harus dipahami pula adalah dengan kemajuan zaman melalui teknologi yang berusaha menggantikan interaksi yang bersifat langsung tetap tidak bisa menggantikan hubungan emosional antara tenaga pendidik dan siswa. 


\section{Pendahuluan}

Dewasa ini perkembangan zaman sudah sedemikian maju serta terjadi perubahan yang begitu cepat terjadi. Abad 21 atau abad milenium perubahan terkait informasi dan teknologi juga menjadi sangat cepat pula. Perkembangan yang pesat ini ini tentu akan berpengaruh terhadap sektor lain, seperti inovasi yang terus menerus dan berdampak pada bidang industri produk serta industri jasa yang berakibat pula terhadap tata penggunaan dan tata pemasaran. Era ini disebut dengan era disrupsi atau ada pula yang menamakan dengan era indutri 4.0.

Perubahan zaman yang semakin pesat ini tentu memaksa semua sektor untuk melakukan inovasi agar dapat mempertahankan eksistensinya. Termasuk bidang pendidikan, lahirnya generasi milenia yang sudah terhubung dengan teknologi sejak lahir tentu menjadi sebuah pelengkap perubahan zaman (Khobir 2009) Perubahan tentu harus disikapi melalui adaptasi terhadap keadaan yang berkembang dengan pesat. Belakangan ini perubahan paradigma dalam kehidupan, memunculkan sikap individualitis akibat dari semakin kompleksnya kehidupan masyarakat dan serta semakin sibuknya masyarakat menyikapi perkembangan yang begitu cepat.

Seiring berkembangnya teknologi digital di Indonesia dengan menyadari kebutuhan siswa yang berada pada kebijakan kurikulum yang menghendaki penggunaan jam belajar sistem fullday school. Maka hadirlah beragam media alternatif untuk menjangkau siswa tanpa melanggar sistem justru sebagai alat pemenuhan kebutuhan siswa dalam belajar lebih efisien dan efektif.(Efendi 2018, p.176). Pada era disrupsi ini, semua dimensi kehidupan mengalami pergeseran tidak hanya dalam dunia bisnis tapi juga berpengaruh terhadap dunia pendidikan sehingga menuntut adanya inovasi dalam kurikulum yang sesuai dengan eranya (Baharun 2017).

Pendidikan yang dalam definisi yang terdapat pada (Undang-Undang Nomor 20 Tahun 2003 Tentang Sistem Pendidikan Nasional 2003) tentang sistem pendidikan nasional menyebutkan bahwa pendidikan merupakan usaha atas dasar kesadaran dan terencana dalam upaya mewujudkan suasana belajar dan suasana yang terencana dalam usaha untuk mempunyai kekuatan spiritual dan keagamaan, pengendalian terhadap diri, kepribadian, kecerdasan, serta akhlak mulia dan keterampilan yang diperlukan dirinya, masyarakat serta bangsa dan negara. Definisi pendidikan tetap mendasarkan pada usaha dalam memperbaiki diri pembelajar, namun pembelajar, guru maupun pemerintah tetap harus mencermati perubahan atau suasana yang selalu berkembang dalam zaman yang semakin menuntut manusia untuk memperhatikan serta menguasai teknologi dalam kehidupannya.

Dunia pendidikan mendesak pemerintah dan pendidik untuk merealisasikan dan memperbaharui strategi implementasi kurikulum 2013 untuk merealisasikan dan memperbaharui strategi implementasi kurikulum 2013 untuk menghadapi era disrupsi tersebut demi peningkatan kompetensi dan inovasi akademis (Machali 2014 , 5). Perubahan dalam dunia pendidikan berbasis daring atau apapun yang hendak dilakukan pemerintah tentu harus mengakomodasi perubahan yang begitu cepat dalam dunia yang saat ini berbasis teknologi informasi. Perubahan ini tentu menjadi sebuah keniscayaan dan memang harus diantisipasi dengan usaha tanpa kenal lelah dalam mewujudkan hal tersebut. 
Saat ini efisiensi serta segala perubahan yang semakin cepat tentu membuaat manusia harus dan mampu untuk menciptakan inovasi baru. Seperti kita ketahui bersama revolusi 3.0 telah mulai bergeser dan saat ini kita telah sangat familiar dengan era revolusi industry 4.0. dimana saat ini kita telah melaksanakan evolusi gaya hidup dari zaman penggunaan peralatan dan mesin sederhana menuju media atau alat yang memiliki teknologi informasi dan komunikasi yang akan memudahkan manusia dalam melakukan aktivitas sehari-hari (Bakhtiar 2018, 87-88). Mewujudkan komunikasi yang efektif dalam bidang pendidikan seperti halnya komunikasi pada umumnya. Hal yang perlu diperhatikan tersebut antara lain; 1) Respect, 2) Empathy, 3)Audible, 4) Clarity, 5) Humble (Wisman 2017, 651).

Tulisan ini mencoba memaparkan terkait tantangan pendidikan saat ini. Komunikasi dalam pendidikan tentu berwujud interaksi aktif antara tenaga pendidik dengan siswa. Komunikasi berupa interaksi yang akrab tentu menyebabkan proses pembelajaran menjadi bermakna. Pada komunikasi interpersonal tenaga pendidik menjadi sebuah upaya pembentukan relasi yang akrab antara tenaga pendidik dan siswa. Menjadi salah satu faktor yang mempengaruhi proses pembelajaran. Interaksi yang mempengaruhi dinamika komunikasi dalam pembelajaran antara lain tujuan pendidikan, pendidik, anak didik. Tantangan tersebut menuntut beralihnya pola pendidikan yang dulu hanya menekankan pola pembelajaran offline menjadi pola pembelajaran yang juga harus menyertakan pembelajaran daring atau online.

Hal ini tentu menjadi sebuah momentum agar bidang pendidikan harus mempersiapkan sarana prasarana pendukung dalam rangka terus meningkatkan kualitas manusia Indonesia sebagai sebuah upaya mempersiapkan serta mengantisipasi perubahan zaman sehingga pendidikan (khususnya) pendidikan Islam dapat bersinergi dengan kemajuan zaman tanpa meninggalkan kepribadian bangsa.

\section{Kajian teori}

Kemajuan teknologi adalah suatu bagian dari konsekuensi modernitas serta merupakan sebuah upaya eksistensi manusia. Hal tersebut tentu dapat pula berdampak negatif sebagai akibat upaya manusia untuk mengatasinya. Dengan adanya consciousness (kesadaran) kita meyakini bahwa generasi mendatang tentu dapat menjadi lebih baik, dapat menjadi lebih smart dan seharusnya lebih bermartabat (Ngafifi 2014, 43). Manusia adalah makhluk hidup yang sifatnya dinamis dan akan terus berkembang. Manusia akan selalu menemukan sebuat metode yang dapat memudahkan hidupnya, akan selalu berkompetisi serta akan selalu belajar.

Komunikasi pendidikan adalah sebuah proses penyampaian pesan atau penyampaian informasi, yang merambah bidang atau peristiwa pendidikan. Proses pembelajaran merupakan sebuah proses komunikasi. Pesan yang disampaikan dapat berupa isi/ ajaran, yang dituangkan ke dalam symbol-simbol komunikasi, baik verbal maupun non verbal (Naway 2017, 58)

Komunikasi merupakan proses sistematik di mana individu-individu saling berinteraksi sampai menciptakan simbol-simbol dan menafsirkan makna. Salah satu area yang lebih mengasyikan dari bidang komunikasi modern adalah media dan teknologi baru (Wood, 2004). Pembelajaran efektif ditunjukkan oleh ketepatan komponen-komponen yang digunakan untuk mencapai tujuan belajar itu sendiri. Killen (1988) 
mengungkapkan hakekatnya pembelajaran berkualitas dan efektif berkaitan pencapaian hasil belajar yang ditetapkan, melalui proses pembelajaran yang dirancang oleh pengembang program (Basori 2014, 41).

Istilah disrupsi telah dikenal puluhan tahun lalu, tetapi baru populer setelah guru besar Harvard Business School, Clayton M. Christensen, menulis buku berjudul The Innovator Dilemma (1997). Buku ini berisi tentang persaingan dalam dunia bisnis, lebih khusus inovasi. Disrupsi atau disruption dapat diartikan sebagai gangguan bahkan bisa diartikan pula dengan kekacauan; gangguan atau masalah yang dapat mengganggu suatu peristiwa, proses atau keadaan (disturbance or problems which interrupt an event, activity, or process). Dalam Kamus Besar Bahasa Indonesia (KBBI) disebutkan bahwa disrupsi adalah tercabut dari akarnya. Apabila kita telaah bersama saat ini proses pembelajaran tentu sangat terbantu dengan adanya sumber belajar yang begitu mudah. Kemudahan tersebut dapat terlihat melalui materi pelajaran ataupun kuliah yang dapat diperoleh melalui internet. Selain itu juga kemudahan tersebut dapat dilakukan melalui penyampaian materi yang tidak hanya melalui cara konvensional seperti penyampaian dalam kelas baik kelas online. Tetapi kelas pun sekarang bisa menggunaakan perantara teknologi informasi yang mampu menciptakan kelas online tanpa harus dihadari secara fisik.

Perkembangan ini tentu juga harus diimbangi dengan perbaikan kualitas manusianya. Memperbaiki kualitas manusia dapat dilakukan melalui proses pendidikan. Berdasarkan definisinya pendidikan diartikan sebagai suatu usaha sadar dan terencana dalam mewujudkan suasana belajar dan proses pembelajaran yang bertujuan agar siswa atau peserta didik dapat aktif untuk menimbulkan potensi dirinya untuk mengembangkan kekuatan spiritual atau keagamaan, mampu mengendalikan diri serta membentuk kepribadian, meningkatkan kecerdasan, menumbuhkan akhlak mulia serta keterampilan yang dibutuhkan pribadinya, masyarakat serta bangsa dan negara.

Era disrupsi seperti saat ini tentu menawarkan kemudahan dalam berbagai hal, salah satunya adalah bidang pendidikan yang mendapat pengaruh baik positif maupun negatif. Salah satu dampak postif kemajuan teknologi dalam bidang pendidikan adalah untuk mencari referensi tidak harus pergi ke perpustakaan atau membeli buku. Saat ini informasi terkait tema atau topik apa saja dapat diperoleh melalui internet yang menyajikan akses big data atau meta data yang tentu saja menyajikan data yang sangat banyak bagi pencari informasi.

Perkembangan ini tentu terkait dengan apa yang ditulis oleh Alvin Toffler (1980) yang menyebutkan bahwa akan ada tiga gelombang besar yang melanda dunia, dalam tulisannya disebutkan tiga gelombang yang telah dan akan dihadapi manusia, gelombang tersebut adalah;

1) The First Wave is the settled agricultural society which prevailed in much of the world after the Neolithic Revolution, which replaced hunter-gatherer cultures.

2) The Second Wave is Industrial Age society. The Second Wave began in Western Europe with the Industrial Revolution, and subsequently spread across the world. Key aspects of Second Wave society are the nuclear family, a factory-type education system and the corporation. Toffler writes.

3) The Third Wave is the post-industrial society. Toffler says that since the late 1950s most countries have been transitioning from a Second Wave society into a Third Wave society. 
He coined many words to describe it and mentions names invented by others, such as the Information age.

IImu pengetahuan yang mendukung perubahan dengan cara memanfaatkan teknologi informasi dan komunikasi tentu berdampak pada tingkah laku masyarakat. Perubahan tingkah laku akibat penggunaan sarana-prasarana pendukung pada media sosial yang telah menjadi bagian gaya hidup atau interaksi masyarakat, dapat disimpulkan bahwa terdapat potensi perubahan perilaku individu di masyarakat yang tentu dap at memunculkan kerawanan sosial berupa sifat egois dan anti sosial lainnya.

Inovasi lainnya yang muncul untuk memanfaatkan teknologi informasi adalah 3D Printing, Big Data, Bitcoin, Teknologi Cloud, Internet og Things, MOOCs (Masive Online Open Course) atau kursus online besarbesaran, dan media sosial (Dotsika and Watkins 2017). Kursus online pada saat ini memang menjadi pilihan yang sering diambil oleh masyarakat. Startup pendidikan seperti itu dapat kita katakan cenderung terus berkembang dan semakin banyak yang menggunakannya. Melalui situs kompas.com disebutkan bahwa Ruangguru adalah startup di bidang pendidikan yang dibangun oleh Belva Devara dan Iman Usman pada 2014. Tujuan mereka awalnya adalah untuk mempertemukan guru les dan siswa yang membutuhkan bimbingan belajar. Kini keanggotaan Ruangguru telah mencakup 6 juta pelajar dan sekitar 150 ribu guru (Sukmana 2019). Semakin besar jumlah yang menggunakan startup tersebut tentu semakin besar kesempatannya menjadi unicorn lain dan tentu akan berkontribusi bagi ekonomi Indonesia.

J umlah siswa di Indonesia rata-rata berjumlah 45 juta/tahun tentu merupakan jaminan dan peluang bagi penggiat startup pendidikan (edutech) ditambah dengan digitalisasi yang tidak bisa ditinggalkan (Efendi 2018, p.175). Pendidikan merupakan "potensi bisnis" yang dapat dikatakan tidak akan pernah hilang. Pendidikan akan selalu menjadi kebutuhan yang tidak akan pernah bisa diganti dengan pemenuhan kebutuhan lain atau tidak ada benda atau jasa subsitusi lainnya.

Munculnya berbagai perusahaan yang menawarkan kursus yang lebih fleksibel yang tidak mensyaratkan untuk bertatap muka langsung atau hanya melalui media online atau aplikasi tentu menjadi sebuah tantangan kedepannya dalam dunia pendidikan. Kepraktisan tersebut tentu menawarkan kemudahan akses dan lainnya. Munculnya penyedia jasa ini menjadi gambaran bahwa era disrupsi memang awalnya adalah murni bisnis yang menawarkan inovasi dan mulai dari kelas bawah dan terus meningkatkan kualitas. Dampak era disrupsi dalam pendidikan tentu akan semakin besar dikarenakan manusia sebagai pendukung utama bidang ini akan terus mengupayakan sisi praktis dalam aktivitasnya. Tetapi terkait kurikulum yang muatannya sudah diatur sedemikian rupa tentu akan ada pembatasan terkait perubahan yang besar-besaran dalam hal kontennya.

\section{Metode}

Studi pustaka menempati posisi yang sangat penting dalam penelitian. Walaupun sebagian orang membedakan antara riset kepustakaan dan riset lapangan, akan tetapi keduaduanya memerlukan penelusuran pustaka. Ada perbedaan yang melekat pada riset kepustakaan dengan riset lapangan, perbedaannya yang utama adalah terletak pada tujuan, fungsi atau kedudukan studi pustaka dalam masing masing penelitian tersebut (Khatibah 2011, 38). Sementara dalam riset pustaka, penelusuran pustaka lebih 
daripada sekedar melayani fungsi-fungsi yang disebutkan untuk memperoleh data penelitiannya. Tegasnya riset pustaka membatasi kegiatannya hanya pada bahan-bahan koleksi perpustakaan saja tan pa memerlukan riset lapangan (Zed 2008, 1-2).

Artikel ini menggunakan jenis penelitian library research yaitu sebuah penelitian yang dilakukan melalui pengumpulan data terkait dengan pendidikan dewasa ini, pengumpulan data atau karya tulis ilmiah yang bertujuan untuk melakukan studi kritis dan mendalam dengan mencari bahan pustaka yang relevan. Analisis deskriptif digunakan untuk menganalisa kajian serta membuat kesimpulan dengan data yang valid dan sesuai konteksnya.

\section{Pembahasan}

Prediksi Alvin Toffler dalam karyanya The Third Wave (1980) terkait ciri masyarakat dengan membagi menjadi tiga mungkin dapat kita telaah lebih lanjut. Walaupun buku tersebut sudah lama dan berumur cukup tua namun kesimpulan dari tulisan dia mungkin dapat kita cermati dengan lebih dalam. Dalam tulisannya Toffler membagi fase masyarakat menjadi 3 (tiga) fase. Toffler menyebutkan fase pertama adalah masyarakat agraris dengan durasi tahun sejak 8000 sebelum masehi hingga 1700 masehi yang memiliki ciri bahwa masyarakat hanya memanfaatkan sumber daya alam secara langsung kemudian masyarakat menjadi mampu memelihara dan memproduksi sendiri sumber makanan. Komunikasi pada fase ini dilakukan secara langsung atau melalui proses tatap muka (face to face).

Pada gelombang kedua yang dikenal sebagai masyarakat industri dengan angka tahun sejak 1700 hingga tahun 1970 masehi, memiliki ciri utama bahwa manusia yang hidup pada gelombang ini adalah manusia ekonomi yang telah mengganti tenaga otot sebagai faktor penentu produksi kemudian dapat menemukan mesin sehingga mencapai optimalisasi hasil industri karena peralihan tenaga kerja dari manusia beralih kepada tenaga mesin. Kemudian pada fase ini terjadi mobilitas manusia yang semakin cepat serta banyak terjadi perang di dunia.

Fase terakhir atau ketiga ketiga dikenal sebagai masyarakat informasi dengan angka tahun mulai dari tahun 1979 hingga tahun 2000 masehi yang memiliki ciri mobilitas manusia yang semakin meningkat, dengan intensitas yang sangat padat serta juga memiliki ciri mobilitas informasi berjalan sangat cepat dan menyebabkan tingkat efisiensi sangat tinggi. Ciri masyarakat gelombang tiga ini adalah menjadikan informasi sebagai salah satu kebutuhan hidupnya.

Pendapat dari Alvin Toffler ini tentu menjadi gambaran keadaan zaman pada saat ini. Perkembangan teknologi dan informasi terjadi dengan sangat cepat. Masyarakat terus berubah dan harus beradaptsi dengan kemajuan zaman agar tidak terlalu ketinggalan. Perubahan ini terjadi pula pada bidang pendidikan yang mana setiap peserta didik memiliki handphone sebagai salah satu new media yang dapat memperoleh atau memberi informasi apapun dan kapanpun serta dimanapun mereka berada, baik terkait aspek akademik maupun non akademik.

Di Indonesia saat terjadi krisis dengan ditandai ambruknya sektor riil yang menjadi dampak krisis moneter, pada sisi lain animo belajar di berbagai lembaga pendidikan seperti universitas dan akademi justru malah terjadi peningkatan. Era digitalisasi memperluas peluang sektor pendidikan, tetapi menjadi sebuah 
ancaman bagi institusi yang tidak mampu beradaptasi terhadap kemajuan zaman atau lambat melakukan penyesuaian diri. Universitas yang tidak mampu melakukan penyesuaian tentu tidak akan hilang atau lenyap tetapi adaptasi tentu harus dilakukan agar tidak semakin tertinggal. Universitas tentu harus membuka peluang bagi munculnya pendidikan dengan pemanfaatan internet (Pranggono 2001, 6). Pendidikan mau tidak mau juga harus selalu meng-upgarde bidangnya sehingga dapat menciptakan outputatau lulusan yang mampu memenuhi kebutuhan tenaga kerja terdidik yang ada di Indonesia. Hal ini dikarenakan pendidikan merupakan kebutuhan yang mau tidak mau harus dipenuhi oleh masyarakat selain kebutuhan primer lainnya.

Sebagaimana telah disinggung di atas, pendidikan sebagai bagian dari program dan aktivitas pembangunan tidak luput dari disrupsi. Tuntutan pendidikan jarak jauh dalam jaringan, masuknya perguruan tinggi asing, revolusi industri 4.0, serta trendyang mengiringi seperti big data, membuat pengelola perguruan tinggi perlu melakukan penataan ulang kurikulum (Leksono 2018, 3). Tantangan dalam dunia pendidikan tentu menjadi hal yang pasti ada. Seperti halnya dengan tantangan terkait kemajuan zaman yang semakin terkait dengan teknologi informasi. Proses digitalisasi dalam kehidupan manusia tentu merupakan hal yang akan terus ada karena ciri-ciri zaman yang semakin lekat atau memiliki keterkaitan dengan teknologi informasi.

Perubahan besar zaman atau yang lebih dikenal dengan istilah disrupsi tentu merupakan sebuah keniscayaan. Disrupsi tidak dapat diartikan hanya sekedar perubahan semata, tetapi disrupsi dapat kita nyatakan sebagai perubahan besar yang mengubah tatanan. Terdapat dua karakteristik atau ciri penting dari sebuah proses disrupsi. Pada bagian pertama perubahan itu sangat mendasar terkait dengan model bisnis atau dengan kata lain inovasi yang ditawarkan berbeda dari sebelumnya. Kemudian bagian kedua adalah disrupsi selalu bermula dari lapisan bawah (/ow-end) yang terus bekerja dan selalu meperbaiki kualitas.

Kemajuan zaman seperti sekarang ini tentu akan menimbulkan dampak baik positif ataupun negatif. Peran para pendidik dewasa ini tentu tidak hanya sekedar memberi atau mentransformasikan pengetahuan semata. Pada masa lalu guru tentu menjadi sumber pengetahuan utama selain buku dan sumber literatur lainnya. Kita harus menyadari pada era digital seperti saat ini guru tentu tidak dapat menyaingi sumber atau rujukan utama generasi milineal dalam belajar seperti mesin pencari seperti google yang tentu dapat memberikan informasi secara lebih cepat. Pendidik/guru/pengajar tentu tidak akan mungkin bisa bersaing dengan mesin terkait hapalan, hitungan serta pencarian informasi. Bicara efektivitas mesin dapat dikatakan unggul dari manusia karena mesin dapat dikatakan lebih pintar, berpengetahuan dan yang paling penting tidak pernah merasa lelah dalam melakukan tugasnya.

Manusia mempunyai kelebihan yang tidak dapat disamakan dengan mesin sampai kapanpun. Manusia mempunyai sisi emosional yang tulus dan tidak bisa dibuat-buat, sedangkan mesin tentu tidak memilikinya. Oleh sebab itu peran guru/pendidik/pengajar harus lebih dioptimalkan melalui pengajaran nilai etika, nilai budaya, nilai kebijaksanaan, serta nilai pengalaman. Karena nilai-nilai tersebut tidak dapat hanya dibaca semata, tetapi memang harus memiliki pendekatan emosional tentunya, dan yang paling penting mesin tidak dapat melakukannya.

Pemberian tugas oleh guru/pendidik/pengajar tentu tidak bisa hanya menggunakan pemberian tugas berupa makalah semata. Karena tugas seperti itu begitu mudah dibuat oleh peserta didik melalui pencarian tema atau topik sejenis melalui internet. Kecuali guru/pendidik/pengajar mau melakukan upaya mencari tahu 
tingkat plagiasi tugas peserta didik terlebih dahulu yang juga dapat dilakukan secara online. Peran guru/pendidik/pengajar tentu dapat mengupayakan makna teks yang dihubungkan dengan konteks. Melakukan kontekstualisasi informasi dan memberikan bimbingan kepada peserta didik. Hal ini tentu membedakan peran antara guru/pendidik/pengajar dengan media di internet yang tidak dapat melakukan hubungan emosional yang terjalin antara guru/pendidik/pengajar dengan peserta didik.

Interaksi edukatif adalah interaksi yang dilakukan secara sadar dan mempunyai tujuan untuk mendidik, dalam rangka mengantar peserta didik ke arah kedewasaannya. Pembelajaran merupakan proses yang berfungsi membimbing para peserta didik di dalam kehidupannya, yakni membimbing mengembangkan diri sesuai dengan tugas perkembangan yang harus dijalani (Naway 2017, 82).

Secara global era digitalisasi akan menghilangkan sekitar 1 - 1,5 miliar pekerjaan sepanjang tahun 20152025 karena digantikannya posisi manusia dengan mesin otomatis (Gerd Leonhard, Futurist). Selain itu diperkirakan pada masa yang akan datang, 65\% murid sekolah dasar di dunia akan bekerja pada pekerjaan yang belum pernah ada di hari ini menurut U.S. Department of Labor report (Dimyati 2018, 12). Semakin berkembangnya kehidupan manusia saat ini, kita tentu harus mengupayakan terjadinya perubahan dalam kegiatan di kelas. Seorang guru/pendidik/pengajar tentu harus melebihi dari sebuah kegiatan rutin seperti monolog di depan kelas. Peserta didik tentu memerlukan adanya guru/pendidik/pengajar yang selalu menekankan perlunya peningkatan kompetensi bagi peserta didik dan memunculkan semangat bagi peserta didik untuk membekali diri dengan kemampuan sebagai insan pembelajar (/earning individuals). Kebutuhan tenaga kerja saat ini juga memerlukan tenaga kerja yang mampu untu terus belajar dalam upaya merespon pengetahuan yang terus berkembang. Selain itu juga harus membekali diri dengan kemampuan problem solving.

Ninok Leksosno memaparkan beberapa kriteria mahasiswa dewasa ini yaitu, proses pembelajaran di kondisikan sebagai penjelajahan pengetahuan oleh mahasiswa atau menjadi learning journey yang menjadi sebuah fase pencarian informasi sebanyak mungkin. Kemudian pendidikan menjadi salah satu cara utama dalam pengembangan karakter, sebagaimana penguatan karakter itu telah tertuang dalam peraturan Presiden nomor 87 tahun 2017 tentang penguatan pendidikan karakter. Selanjutnya adalah mahasiswa menjadi insan pembelajar yang selalu haus informasi dan menjadi insan pembelajar yang paham dan memiliki ragam pendekatan seperti design thinking (merupakan cara penyelesaian masalah yang difokuskan pada people centered yang jelas akan berpusat serta diinginkan dan dibutuhkan oleh pengguna). Kemudian pendidikan saat ini juga harus memunculkan atau menumbuhkan kreativitas pada diri peserta didik. Hal lain yang diharapkan adalah kemampuan bekerja sama yang baik serta mampu memecahkan masalah dengan bijak. Selanjutnya yang tidak kalah penting adalah bagaimana memunculkan kemandirian pada diri sendiri.

Kelancaran komunikasi juga dipengaruhi oleh beberapa factor antara lain adalah 1) Faktor Pengetahuan 2) Faktor Pengelaman 3) Faktor Intelegensia 4) Faktor Kepribadian 5) Faktor Biologis (Naway 2017, 84). Dalam upaya mewujudkan hasil belajar yang lebih baik, maka peran pendidik menjadi sangat penting. Pendidik harus mampu dan membiasakan mempergunakan komunikasi multi arah atau banyak arah. Komunikasi ini tentu tidak hanya melibatkan interaksi antara pendidik dengan peserta didik dan peserta didik dengan peserta didik lainnya. Komunikasi tersebut bisa juga antara kepala sekolah dengan pendidik, pendidik dengan tenaga kependidikan kepala sekolah dengan siswa dan hubungan komunikasi lainnya. Tetapi dewasa ini 
hubungan komunikasi tersebut menjadi kurang intensif dikarenakan adanya pendemi yang mengakibatkan hubungan sosial atau interaksi sosial dilakukan melalui perantara media.

Selain para peserta didik, yang tidak kalah penting adalah bagaimana sosok pengajar ideal dapat terbentuk pada pendidikan saat ini. Kriteria pertama adalah tentu harus memiliki kompetensi keilmuan yang kuat serta memiliki soft skil/ berupa berpikir kritis, kreatif, komunikatif, dan mampu berkolaborasi. Selain hal diatas pengajar juga harus mampu menebar inspirasi bagi peserta didik, mampu menjadi teman bagi peserta didik dan tentu saja harus menjadi teladan bagi mahasiswa. Dalam kaitannya dengan pengembangan ilmu pengetahuan serta teknologi, terdapat dua pilihan besar yang dihadapi oleh bidang pendidikan. Pilihan tersebut antara lain adalah pertama terkait penggunan teknologi yang tepat digunakan untuk masyarakat, apakah high technology, low technology atau mixed technology. Kedua adalah bagaimana reaksi yang diberikan terkait dengan masa depan teknologi. Pilihan tersebut bisa memilih antara:

1) Tetap mempertahankan kondisi atau struktur pendidikan dengan tidak mempedulikan perubahan teknologi,

2) Menyesuaikan kondisi atau struktur pendidikan dengan tuntutan teknologis,

3) Mengubah struktur pendidikan yang ada dan mengembangkan struktur yang bersifat fleksibel serta melakaksanakan dengan segala perubahan kebijaksanaan yang diambil (Nurkholis 2013, 37).

Era modern diidentikkan dengan era masyarakat digital. Setiap aktivitas manusia akan digerakkan melalui serangkaian teknologi digital. Teknologi ini dioperasikan dengan menekan beberapa digit (angka) yang di susun dengan berbagai urutan (Ngafifi 2014, 38). Para penggiat pendidikan dan praktisi serta para guru/pendidik/pengajar tentu harus menyikapi hal ini dengan bijak. Penggunaan teknologi tentu tidak dapat dihindari. Namun yang menjadi hal penting adalah kemajuan teknologi dalam bidang pendidikan tidak akan pernah menggantikan peran dari proses pembelajaran tersebut. Penggunaan media online pada siswa tentu berdampak pula terhadap kegiatan ataupun prestasi akademik siswa pada lembaga pendidikan. Para pengajar/pendidik tentu harus menyadari hal ini dengan bijak. Tetapi kehadiran pendidik/pengajar tentu tidak dapat digantikan oleh alat secanggih apapun, karena hubungan emosional antar siswa dan guru tidak akan pernah dapat digantikan oleh alat/aplikasi/program apapun.

\section{Simpulan}

Prediksi Alvin Toffler dalam tentu menjadi gambaran besar bahwa masyarakat akan selalu berkembang seiring zaman yang juga akan terus berubah. Saat ini tidak dapat kita pungkiri adalah bahwa teknologi informasi menjadi sebuah kebutuhan hidup yang juga berkembang dengan sangat cepat. Hal ini berdampak pula terhadap dunia pendidikan. Kemajuan ini tentu berdampak positif maupun negatif, peran pendidik terasa tersaingi dengan adanya teknologi yang memudahkan peserta didik untuk belajar melalui internet atau melalui aplikasi yang mampu memberikan kemudahan belajar kepada peserta didik. Namun, walau bagaimanapun posisi guru pun tetap tidak dapat digantikan. Guru saat ini tentu juga harus membekali diri dengan kemampuan yang lebih lagi terutama penguasaan teknologi dalam hal pembelajaran. Guru memiliki 
kelemahan dibanding google dalam hal kecepatan maupun ketepatan tetapi memiliki empati yang tidak dapat terganti.

Era disrupsi yang mencoba memberi variasi interaksi sosial melalui media daring, sedikit banyaknya pola komunikasi secara langsung melalui tatap muka dapat dilakukan melalui perantara media. Ketika masa pandemi seperti sekarang ini, maka pola komunikasi pembelajaran secara langsung mulai digantikan dengan pola interaksi secara tidak langsung dan mendapat respons yang beragam. Sehingga hal tersebut menjadi proses evaluasi pada masa mendatang.

\section{Referensi}

Baharun, Hasan. 2017. Pengembangan Kurikulum : Teori Dan Praktik (Konsep, Prinsip, Model, Pendekatan, Dan Langkah-Langkah Pengembangan Kurikulum PAl). Yogyakarta: Cantrik Pustaka.

Bakhtiar, Sony. 2018. "Kebijakan Pendidikan Kosmopolitan Muhammadiyah Di Tengah Tantangan Era Disrupsi." The Journal of Society \& Media 3 (1).

Basori. 2014. "Efeltifitas Komunikasi Pembelajaran Online Dengan Menggunakan Media E-Learning Pada Perkuliahan Body Otomotif." JIPTEK VII (2): 39-45.

Dimyati, Muhammad. 2018. "Tantangan Riset Di Era Disrupsi Dan Globalisasi." Semarang: Direktorat Jenderal Penguatan Riset dan Pengembangan KEMENRISTEK DIKTI.

Dotsika, Fefie, and Andrew Watkins. 2017. "Identifying Potentially Disruptive Trends by Means of Keyword Network Analyisis." Technological Forecasting and Social Change 119: 114-27.

Efendi, Neng Marlina. 2018. "Revolusi Pembelajaran Berbasis Digital (Penggunaan Animasi Digital Pada Start Up Sebagai Metode Pembelajaran Siswa Belajar Aktif)." Habitus: Jurnal Pendidikan, Sosiologi Dan Antropologi2 (2): 173-82.

Khatibah. 2011. "Penelitian Kepustakaan." Jurnal Iqra 05 (01):36-39.

Khobir, Abdul. 2009. "Pendidikan Agama Islam Di Era Globalisasi." Edukasia Islamika 7 (1).

Leksono, Ninok. 2018. "Pembangunan, Pluralitas, Dan Era Disrupsi.” Yogyakarta: Universitas Sanatha Dharma.

Machali, Imam. 2014. "Kebijakan Perubahan Kurikulum 2013 Dalam Menyongsong Indonesia Emas Tahun 2045." Jurnal Pendidikan Islam 3 (1): 71-94.

Naway, Fory Armin. 2017. Komunikasi Dan Organisasi Pendidikan. Gorontalo: Ideas Publishing.

Ngafifi, Muhammad. 2014. "Kemajuan Teknologi Dan Pola Hidup Manusia Dalam Perspektif Sosial Budaya." Jurnal Pembangunan Pendidikan :Fondasi Dan Aplikasi 2 (1):33-47.

Nurkholis. 2013. "Pendidikan Dalam Upaya Memajukan Teknologi." Jurnal Kependidikan 1 (1): 24-44.

Pranggono, Bambang. 2001. "Pendidikan Tinggi Di Era Digital Dan Tantangan Bagi UNISBA." MimbarXV11 (1): $1-19$.

Sukmana, Yoga. 2019. "Hasrat Ruangguru Menjadi Unicorn, Startup Bernilai 1 Miliar Dollar AS." Https://Ekonomi.Kompas.Com/Read/. 2019.

https://ekonomi.kompas.com/read/2019/02/04/110200326/hasrat-ruangguru-menjadi-unicornstartup-bernilai-1-miliar-dollar-as.

Undang-Undang Nomor 20 Tahun 2003 Tentang Sistem Pendidikan Nasional. 2003. Sekretariat Negara RI.

Wisman, Yossita. 2017. "Komunikasi Efektif Dalam Dunia Pendidikan." Jurnal Nomosleca 3 (2): 646-54.

Zed, Mestika. 2008. Metode Penelitian Kepustakaan. J akarta: Yayasan Obor Indonesia. 